\title{
Ocorrência de mancha alvo, causada por Corynespora cassiicola, em alface cultivado em hidroponia no Brasil
}

\author{
Israel Pereira dos Santos ${ }^{2}$, Shirley Souza Cardoso ${ }^{2}$, Luiz Sebastião Poltronieri ${ }^{1}$, Jaqueline Rosemeire Verzignassi ${ }^{1}$, \\ Ruth Linda Benchimol ${ }^{1}$
}

${ }^{1}$ Embrapa Amazônia Oriental, Tv. Enéas Pinheiro, S/N, CEP 66095-100, Belém, PA, e-mail: poltroni@cpatu.embrapa.br

${ }^{2}$ Universidade Federal Rural da Amazônia, Av. Perimetral, 2501, 66077-530, CP. 917, Belém, PA.

Data da chegada: 23/05/2006. Aceito para publicação em: 15/01/2007.

A partir do momento em que os produtores passaram a cultivar intensamente as plantas hortícolas em ambientes protegidos, agravaramse os problemas de doenças nesses sistemas, que aumentaram ainda mais com a utilização sucessiva das áreas de plantio. A hidroponia surgiu como opção para reduzir as perdas causadas por doenças, principalmente daquelas causadas por patógenos que apresentam fase saprofítica no solo, em virtude da ineficácia ou inviabilidade econômica do seu controle químico ou cultural (5). Entretanto, atualmente, sabe-se que plantas cultivadas em hidroponia estão sujeitas, praticamente, às mesmas doenças, tanto da parte aérea quanto das raízes, que ocorrem tanto em cultivo protegido como em convencional. Depois de estabelecidas, essas doenças podem se desenvolver até com maior rapidez sob hidroponia, visto que as condições de temperatura e umidade são normalmente mais favoráveis (4). No Município de Castanhal, PA, foi observada a ocorrência de uma doença em cultivo hidropônico de alface, com 30 dias de idade, causando manchas foliares (Fig. 1). Nos estádios iniciais da doença, as folhas apresentavam pequenas lesões escuras de aproximadamente $3 \mathrm{~mm}$ de diâmetro que, com o passar do tempo, aumentavam de tamanho e coalesciam, necrosando totalmente as folhas e tornando-as impróprias para comercialização. Após o isolamento e incubação do patógeno, observou-se a formação de colônias fúngicas de cor cinza, com micélio aéreo de aspecto aveludado e cotonoso. Os conídios apresentaram forma cilíndrica com base truncada, possuindo de dois a 10 septos e medindo de 13,2 (média menor) a 83,6 $\mu \mathrm{m}$ (média maior) de comprimento e 6,6 (média menor) a $11 \mu \mathrm{m}$ (média maior) de largura, características correspondentes ao fungo Corynespora cassiicola (Berk. \& Curt.) Wei, agente causal da mancha alvo em várias culturas agronomicamente importantes, conforme descrito em Ellis (2). A

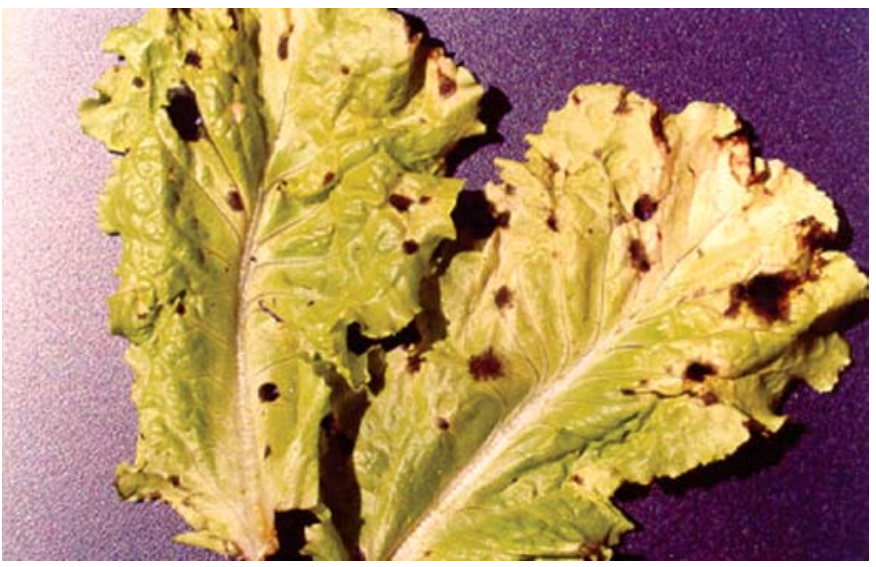

Figura 1. Sintomas causados por Corynespora cassiicola em folhas de alface cultivado em hidroponia.

patogenicidade foi comprovada após quatro dias da inoculação em folhas de plantas sadias da mesma variedade.

Há registros da ocorrência de C. cassiicola no Estado do Pará sobre juta, cacaueiro, tomateiro, hortência, pimenteira longa, aceroleira e mamoeiro $(1,3,6,7,8,9,10,11)$ e, em cultivo protegido, sob estufas plásticas, Verzignassi et al. (12) também encontraram o patógeno causando epidemias em pepino tipo "japonês" no Noroeste do Estado do Paraná.

Com o objetivo da verificação de escala de hospedeiras, os isolados obtidos de folhas de alface foram também inoculados em folhas destacadas de aceroleira, abóbora, pimenteira-do-reino, pimenteira longa, seringueira, cacau, tomateiro, cacau, caupi e hortênsia, não causando sintomas da doença apenas nesta última espécie. 